Федоренко Т. О., аспірант ДВНЗ «Київський начіональний економічний університет імені Вадима Гетьмана» м. Київ, Україна

DOI: https://doi.org/10.30525/978-9934-26-145-9-8

\title{
ІНСТРУМЕНТИ ДЛЯ КІЛЬКІСНОГО АНАЛІЗУ НАЦІОНАЛЬНИХ КУЛЬТУР
}

Економічне зростання в теорії має набір класичних компонентів - інновації, інвестиції, технології, продуктивність праці, але на практиці рецепти економічного дива в різних країнах дають різні результати. Економічні ресурси, рівень розвитку інституцій, політичний режим, культурні цінності відрізняються в багатьох країнах. I саме ці фактори обумовлюють різницю в економічних досягненнях.

Розвиток інститутів в суспільстві, дотримання прав індивіда залежить від культури та цінностей. Культура має колективний характер, iї ядром $є$ цінності, вона визначає соціальні норми та формує економічну поведінку індивіда. Відмінності у національних культурах найбільш очевидні саме в цінностях.

Існує декілька моделей для виміру культури і цінностей, порівняння відмінностей одних культур від інших, зокрема модель Г. Гофстеде, Р. Інглегарта, Ш. Шварца, дані проекту «Глобальне лідерство та ефективність організаційної поведінки» (GLOBE).

Індивідуалізм $\epsilon$ найбільш популярною та зручною для порівняння категорією у сфері міжкультурних досліджень. Країни, що мають вищий рівень індивідуалізму, як правило, мають вищий рівень економічних показників, зокрема ВВП на душу населення [1]. Індивід, його можливості, культура, освіта $є$ однією зі складових економічного розвитку. Індивідуалізм безпосередньо пов'язаний з приватною власністю і верховенством закону, який має захищати цю власність. 
Індивідуалістична культура продукує інновації, i поряд 3 інституційними та іншими факторами, стимулює довгострокове економічне зростання. Індивідуалістична і колективістська культури мають як переваги, так і обмеження. Але з позицій інновацій та довгострокового економічного зростання, індивідуалізм має динамічний ефект, а колективізм - статичну дію [2].

Індекс владності (PDI, Hofstede) відображує ступінь, з якою суспільства приймають повноваження влади, статусні привілеї та соціальну нерівність. Високий рівень владності притаманний ієрархічним, авторитарним суспільствам. Низький рівень владності притаманний суспільствам, у яких відносини будуються на засадах рівності, незалежно від статусу, статі або віку.

Рівень владності, ієрархічність, статус можуть виступати чинниками корупції та гальмувати економічне зростання країни. Країни, яким притаманний низький рівень владності, мають прозоре державне управління, країни з високим рівнем владності більше схильні до корупції.

Існують суттєві відмінності між західними та східними культурами. Країни Східної Азї є більш колективістськими і мають іншу систему організації суспільства. Китай, Сінгапур, Південна Корея та Японія демонструють високий рівень владності та низький рівень корупції. Культура цих країн формувалась під впливом конфуціанської етики, для них характерним $\epsilon$ шанобливе ставлення до старших, повага до правил, інститутів та високий рівень державного контролю. Цінується наполеглива праця, в системі державного управління надається перевага меритократії.

Культурний вимір Г. Гофстеде має і свої недоліки. Культура $є$ динамічним явищем і відповідно може змінюватись 3 часом. Показники було визначено десятки років тому, 3 того часу відбулись істотні економічні і соціокультурні зміни. Проте, як свідчать останні дослідження, з урахуванням соціальних змін культурні показники країн змінюються паралельно, отже відстані між країнами залишаються приблизно в тих самих межах [3]. 
Важливим аспектом культурного аналізу $\epsilon$ показник однорідності культур. Країни з високою густотою населення, дефіцитом природних ресурсів, наявними загрозами природного та воєнно-політичного характеру, як правило, демонструють спільні цінності та є культурно однорідними. Зовнішні загрози забезпечують високу соціальну координацію та формують ціннісний i культурний консенсус, коли переважна більшість суспільства має спільні цінності.

Проте, не всі країни є гомогенними. Внаслідок міграції, тривалої колонізації, примусового виселення корінних народів та заселення територій іншими народами відбувається розмивання національної ідентичності. Як наслідок, країни стають культурно неоднорідними, суспільства вже мають менше єдності і менше спільних цінностей. Неоднорідність культур ускладнює аналіз впливів культурних цінностей на економічний розвиток та суспільство. Попри це культурні виміри надають середні оцінки для країни і продовжують використовуватись в теорії і практиці міжкультурних досліджень.

\section{Література:}

1. Hofstede G. (2011) Dimensionalizing Cultures: The Hofstede Model in Context. Online Readings in Psychology and Culture, 2(1). DOI: https://doi.org/ 10.9707/2307-0919.1014.

2. Yuriy Gorodnichenko \& Gerard Roland, 2017. "Culture, Institutions, and the Wealth of Nations," The Review of Economics and Statistics, MIT Press, vol. 99(3), pages 402-416, July.

3. Beugelsdijk, Sjoerd, Robbert Maseland, and André Van Hoorn. "Are Scores on Hofstede's Dimensions of National Culture Stable over Time? A Cohort Analysis." Global Strategy Journal, 5.3 (2015): 223-240. 